


\author{
Katarzyna Wojciechowska* \\ Kazimierz Wielki University in Bydgoszcz
}

\title{
PREPARING A PRESCHOOL AGE CHILD FOR TOURISM AND LOCAL HISTORY EXPLORATION
}

\begin{abstract}
In preschool education the process of preparing a child for the future role of a tourist is of great importance. The way attitude towards tourism and the knowledge of local history is shaped in kindergarten, will decide upon intensity and value of adult generations' tourism. The process of initiating tourism-related activity and interest in the surrounding cultural, natural and social reality takes place mainly when children participate in field trips. The article presents excursion's role in shaping a tourist behaviour in child's comprehensive development. The analysis of a survey conducted among teachers and parents has been made in order to assess the respondents'opinions on the conditions and the importance of organizing trips in the development of social, cognitive, emotional and health areas of a child's personality as well as child's commitment and preparation for tourism.
\end{abstract}

Keywords: tourism in kindergarten, field trip as a type of tourism, preschool-aged child

\section{Introduction}

Tourism and local history are areas of human life in which one participates because of the need and willingness to explore local and distant environment, the need for rest, relaxation and the need for experiencing emotions, a rapture. An important factor of tourism - local history studied by an adult is to shape the right attitude towards it from an early age. Fostering interest in learning about

\footnotetext{
* E-mail address: k-woj@wp.pl.
} 
the country of origin and using its recreational resources as early as kindergarten, is the best investment in the development of regional and national tourism. In the process of preparing a child to participate in social life, including involvement in tourism, the regional education importance is emphasized. Teachers, using different organizational forms and working methods in the kindergarten, influence a child to gradually shape the features and attitudes of a future tourist such as: an affection for the surrounding reality, an attachment to native land, a knowledge of local public services and an ability to act appropriately in public, an interest in the region's history and respect for local customs and traditions as well as knowledge of the elements which characterize a given locality. The didactic - educational process regarding the field of regional education in a kindergarten emphasizes the need to shape children's sense of their own identity as a basis for their involvement in the functioning of the environment as well as being open to other communities and cultures. ${ }^{1}$

The aim of this study is to identify the role of preschool education as an important part of preparing a child for the role of a tourist and encouraging their cognitive and emotional interest in local history. The author's intention is also to show the importance of a field trip as a form of introducing preschool children to tourism and a way for their comprehensive development. Another aim is to present the results of the survey concerning teachers' and parents' views on the importance of a field trip in a full development of a child's personality, mainly including their interest in local history.

\section{Field trip as the best form of tourism and gaining knowledge about local history for the preschool child}

One of the forms of regional education which prepares a child for the future role of a tourist and helps the child to experience the first contact with the forms of local history exploring is a trip. It plays a huge role in the comprehensive development of all areas of a preschooler's personality. During a trip, a teacher gives children an opportunity to gain experience, knowledge, habits, skills related to tourism and inspires them to be active, to interact with the environment. A field

1 A. Budniak, Social-environmental education of preschool and primary school aged children, IMPULS, Kraków 2010, p. 123. 
trip is the most interesting and proper form of introducing nature to preschoolers, discovering its secrets and creating and emotional connection with it.

Children's participation in excursions, which are the main form of tourism, effects:

- knowledge of a local environment and a child's place of residence,

- harmonious psychophysical development,

- strengthening the habit of spending time outdoors regardless of the time of year, even on rainy days, building up resistance to weather changes and difficulties of being outdoors,

- solidifying interests in different forms of physical activity possible to practice in the field,

- satisfying the hunger for adventure and experience, enriching child's personality,

- being awarded with the "Seven-league boots" ${ }^{2}$ badge (The program is implemented in the cooperation with PTTK. It is designed for children under the age of 10 . The main objective of the program is to get the silver and gold "Seven-league boots "Hiking Tourism Badge by encouraging parents to hike and explore a local environment along with children, gradually bond with nature, raise awareness concerning nature - fauna and flora).

Preschool children participate in such forms of tourism as: auto-tourism, vacation, foreign tourism, holiday trips. But a field trip is the most popular method fulfilling the leisure and cognitive functions, and shaping social attitudes of a preschooler. ${ }^{3}$ In general, a kindergarten organizes several shorter and longer field trips. The longer ones, lasting all day, have a tourism - local history studying character. Due to children's age, they require a very precise and conscientious preparation, food organization, places to rest, caring adults, safe transport. M. Studzińska ${ }^{4}$ stresses that walks and excursions are a desirable, but a difficult for a teacher form of working with children. They require a specific preparation, taking into account:

- children's physical abilities associated with reaching the desired location,

- knowledge of the area,

2 T. Łobożewicz, Sightseeing and tourism at school, WSiP, Warszawa 1985, pp. 30-31.

3 Ibidem, p. 30.

4 M. Studzińska, Pre-school children learn about nature, WSiP, Warszawa 1989, p. 103. 
- purpose and subject of either the walk or excursion,

- knowledge of objects which children will observe.

Trips organized for preschoolers, especially the older ones, are a source of great excitement and joy. Children's need to express the feelings and experiences during trips translates into the language of art, symbols, gestures, facial expressions, etc. Well organized excursion is an opportunity to gain knowledge about the surrounding nature and how it changes during the year. It is especially valuable that children can experience direct contact with reality and can observe natural objects and multilateral conditioned processes and phenomena. The participation in field trips shapes an ability to observe nature, is conducive to deepening and developing interests, raises sensitivity to the beauty of nature and the desire to take care of the environment, teaches acquiring knowledge through direct contact with nature. ${ }^{5}$ In the same way preschool children explore the social, cultural, historical reality developing cognitive curiosity, expressed in the quest to discover the peculiarities of the phenomena, dependencies and regularities. ${ }^{6}$

\section{Own research objectives}

Due to the excursion having such a large impact on shaping the personality of a young child, it has been made the subject of a multi-stage research. ${ }^{7}$ The first part, presented in this study, is to recognize the opinions of kindergarten teachers and parents on the role of trips in the development of a preschool age child and in preparing them for the role of a tourist. At this stage, the answers to the following questions are sought: how the teachers choose a destination, what factors determine their decision? What attitude do children and teachers have towards organizing and participating in excursions? To what extent participating in trips shapes cognitive curiosity and interests of preschoolers? To what extent children's participation in trips improves their health and physical fitness and shapes patriotic and socio - moral attitudes? What measures do parents take to shape positive attitudes towards tourism and studying local history among the family?

\footnotetext{
5 A. Budniak, Social-environmental education..., pp. 88-89.

6 K. Denek, Trips in the modern school, ERUDITUS, Poznań 1997, p. 39.

7 K. Wojciechowska, Excursion as a basic form of tourism and sightseeing in the preschool aged child's education, Rozprawy Naukowe AWF we Wrocławiu No. 46, Wrocław, pp. 212-218.
} 
The concept of the research is based on the method of the diagnostic survey. The questionnaire for teachers and parents has been employed. The sample includes 30 teachers and 120 parents. There are also interviews conducted among 50 preschoolers in accordance with the questionnaire. Qualitative data analysis have provided answers to the questions as above.

\section{Opinions of teachers and parents on the value of field trips}

The value of a fieldtrip in regard to acquiring knowledge and shaping attitudes is to a large extent determined by adapting its destination. Therefore, teachers must take into account different circumstances when making the final decision. Certainly, children's interests and curriculum requirements serve as guidelines. Organizational and financial capabilities of kindergarten and parents have a considerable impact on choosing travel destinations. Planning trips should be accompanied by a full understanding of the goals that the teacher intends to achieve. They are different for each excursion. This is due to the child's needs and the trip's role, whether it is supposed to be a source of acquiring new knowledge, a discovery of a previously unknown to a child piece of reality, or to serve as a repetition, collection, deepening, consolidation of the previously known concepts. ${ }^{8}$

When choosing a social and natural environment, which is to be the travel destination, its didactic-educational values should also be taken into account. According to the respondents, the trips are most often taken to locations where children can directly observe nature, that is: forest, meadow, park, river, zoo, botanical garden and - as mentioned by a few scholars - horse stable. Other venues include: planetarium, museum, library, cinema. Unfortunately, trips designed to familiarize children with various workplaces and occupations (shop, pharmacy, health center, a shoemaker etc.) are organized less frequently. Therefore, children lose the opportunity to get to know the specifics of the work, the respect for it, how it is organized, interesting facts about it which thus results in lowering the level of their occupational pre-orientation. Teachers, asked about the factors of choosing travel destination, stated that they mainly follow the curriculum requirements, children's interests and parents' expectations.

$8 \quad$ K. Denek, Trips..., p. 49. 
Children's interest in trips is enormous. They themselves declare it during the interviews, and the teachers confirm it. Asked about pupils' stance towards participating in field trips, teachers' survey responses all indicated a very positive, enthusiastic attitudes of children. Interestingly, the teachers claim that the kind or location of a trip makes no difference to the children. The mere fact that children get to spend longer time together outside the walls of the kindergarten, brings them joy and makes them anticipate it. According to the teachers, children's joy can sometimes be so great that at first it is difficult to control their emotions during a trip. In the interviews, children enthusiastically talked about excursions, in which they participated and they all agreed that "the trip days" are their favorite days in kindergarten. They gave arguments to support it including: a coach journey, al fresco dining, participating in games, getting to know the unknown, exploring interesting places, watching a variety of animals and plants previously seen only in pictures, horse riding, carriage rides, travelling by boat. They primarily listed those activities which they do not experience in other circumstances. The children talked about the feelings they experience during excursions and they passionately stressed that they would like to travel outside their place of residence more often.

The vast majority of teachers organizes trips for children willingly. They believe that despite the lengthy preparation or bearing a huge responsibility for children, it is an essential form in the didactic-educational process. Teachers give credit to the excursion for not only its cognitive values, but also for how it shapes attitudes towards nature, patriotism, valuable traits and the abilities to work in a team, and it is a rich source of aesthetic experiences. Teachers also stress the recreational importance of field trips which offer the possibility of leisure and spending free time for the benefit of physical and mental health.

Teachers' opinions regarding child's cognitive curiosity development by participating in excursions, were consensual and attributed a great importance to this form of learning. A possibility to explore various objects and phenomena occurring in the natural environment and in the real size is especially valuable. "A child will discover nature, if the mysteries of nature which entice him, make him hungry for knowledge, won't be spoiled by us". ${ }^{9}$ Children, instead of listening to descriptions of nature and watching pictures, can explore nature themselves

9 M. Sawicki, Environmental education in I-III year of primary school, Semper, Warszawa 1997, p. 35. 
through actions and sensory experiences. The multisensory experience of direct communing with nature through sight, hearing, touch, taste is the basis of conceptualizing the environment. During action and sensory experience a child accumulates experiences which are used to correct and modify the concepts forming the basis of understanding the world. A picture of the surroundings, which children build is becoming richer, more diverse and more compatible with reality. The knowledge and experience children have gained must be properly processed to be lasting. Through such forms of processing as a story, poem, drawing, singing, theater, and most of all fun, a repertoire of experience a child gained gives him or her the knowledge and understanding and the basis of a scientific view of the world. ${ }^{10}$

Gaining knowledge through trips gives many opportunities to develop cognitive curiosity, a variety of interests and passions. Activities related with the field of study in glocal history and tourism taken during trips are among the best ways of pictorial familiarizing children with the surrounding reality. An important fact is that this method promotes an effective way of combating verbiage and formalism in school education. ${ }^{11}$ It is acknowledged by the teachers since $90 \%$ of the respondents claim that the children have a very strong interest in new phenomena discovered by observing nature and being a stimulus for an independent exploration. Children ask more questions, browse illustrated books about nature more attentively, talk about their observations during walks and trips with parents, talk to each other about unusual places, animals, plants they have seen. Therefore, participating in a trip can make seemingly familiar phenomena reveal other, more interesting sides, show mutual interdependencies and be a source of developing interests, willingness to deepening knowledge and experiencing interesting sensations through contact with nature. The main role of excursions is: providing its participants with a form of active rest, strengthening their immune system and physical, and mental fitness..$^{12}$ The study has sought to investigate what the teachers' stances towards a trip as a form conducive to caring for health and physical fitness are. It has been established that a slight majority, $61 \%$ of teachers surveyed, believe that a field trip contributes to

10 B. Dymara, S. Michałowski, L. Wollman-Mazurkiewicz, A child in the natural world, IMPULS, Kraków 1998, p. 192.

11 K. Denek, Trips..., p. 51.

12 Ibidem, p. 61. 
the development of children's physical fitness. Teachers emphasized that thanks to children taking part in trips they shape a habit of spending time actively, which is an essential component of a healthy lifestyle. In particular, trips involving walking, hiking promote improving disease resistance and stamina. During exercise, heart and lung function increases, along with metabolism, resulting in increased appetite. Therefore, children are happy, their need for movement is satisfied and they willingly eat meals brought from the kindergarten. Despite this, 36\% of respondents claim that children's participation in excursions contributes little to enhance their health and physical development, and $1 \%$ of respondents deny the value of a trip as a way of proper functioning of the organism and staying fit.

During the trips organized for kindergarten children there are numerous situations which promote the development of socio-moral and patriotic attitudes. Participation in a field trip is a joyful experience for children as it is associated with contact with nature, communing with peers, exploring local and distant places. It is an opportunity to admire the beauty of the country of origin and developing an attachment to it. Excursions taking place in natural conditions create an opportunity for teachers to observe children's behavior and to modify it in case of a lack of discipline, inadequate attitude towards the peers, wildlife or national mementos. Teachers cannot let children litter the place of having fun, recreation or a meal. They pay attention to a correct behavior in a forest, meadow, by a river, so as not to break branches, uproot plants, fright the animals. It is necessary to develop a respect for the work of human mind and hands and protect the natural environment from destruction. ${ }^{13} \mathrm{~K}$. Denek also lists a number of socio-moral educational goals implemented on trips. These include, among others: teaching children to comply with the rules of social coexistence, developing valuable traits and a will, acting with self-discipline and self-control, solidarity, justice, patriotic attitudes, preparing for a role of a team member, teaching a respect for national traditions. ${ }^{14}$

$70 \%$ of teachers surveyed states that a field trip promotes shaping socio-moral and patriotic attitudes with emphasis on attitudes towards nature and the products generated by human activities. Patriotic attitudes are formed during direct contact with the social environment and through progressive exploration of the nearest and more distant environment. It is important to involve

13 Ibidem, p. 56.

14 Ibidem, p. 57. 
preschoolers in preparation, active participation and summarizing the results of trips. It is significant in developing the positive character traits such as responsibility, perseverance, dutifulness, determination, assertiveness, an ability to complete tasks, both independence and an ability to work in a team, and a polite behavior. $16 \%$ of teachers has an opposite view, claiming that a trip is rarely an opportunity to shape socio-moral and patriotic attitudes. The remaining number of the respondents believes that children shape these attitudes only when that is the specific theme and objective of a trip.

A child acquires knowledge and abilities to take care of his or her health at home by accumulating experiences and an individually adapted education. A child should participate in various forms of physical activity along with other family members. For children, physical activity includes: dance, work, recreation, tourism, entertainment, etc. C. Lewicki ${ }^{15}$ distinguishes the most recommended forms of health education in a family which promote creating experiences beneficial health wise, including:

- trips outside the house,

- weekend field trips,

- holiday field trips programs,

- health training,

- outdoor recreation (sport),

- forms of outdoor rehabilitation and therapy.

Among them, forms associated with a longer or a shorter trip, meaning forms of tourism -local history exploring come to the fore. A sample consisting of 120 parents amongst three kindergartens in Bydgoszcz was selected for the study. The researcher was interested in the actions taken by parents in order to create positive attitudes towards tourism and local history exploration. $96 \%$ of parents declare concern for satisfying child's developmental-movement needs. Analyzing the data concerning the types of tourist activity and their frequency provided by the parents, a dissonance between statements and facts can be noticed. Trips outside the city are organized by $31 \%$ of respondents a few times a year. Most parents confine themselves to taking a stroll at weekends. $72 \%$ of families organize excursions during holidays, but only $27 \%$ plan a wider touring programme. Many persons reason that trips meant to explore local history outside the city,

15 C. Lewicki, Factors determining the course, the quality and the effects of health education of 6-11 year old children in the family, WSP, Rzeszów 2001, p. 119. 
require appropriate equipment and also the economic condition of a family imposes certain limitations. Therefore, they most frequently cited stroll as a form of promoting physical activity in children and an opportunity to explore the local environment. A stroll does not require organizing a trip away from home, no special equipment and clothing, can be done at different times of the day, is a form of spending time with family.

\section{Conclusion}

One of the main objectives of early childhood education is to develop a proactive approach to the problems of the local environment, to create an emotional bond with the region, to instill the sense of concern for nature conservation and its proper development. ${ }^{16}$ This postulate is executed most effectively when preschool aged children participate in field trips.

Teachers and their pupils attach great importance to the trip's role. Children describe trips, as very attractive forms of spending time in the kindergarten, the source of enjoyment and merriment. Teachers perceive excursion as an opportunity for achieving many cognitive objectives, learning opportunities and developing children's cognitive curiosity. Children's direct contact with the environment, which is based on observation, measurement, and other practical activities, makes them see the relationships and dependencies between the elements of the natural and social environment and makes them develop a comprehensive picture of the surrounding reality. This knowledge is based on multisensory sensations and is a source of rich aesthetic experiences. Communing with nature teaches children howto perceive its beauty, creates an emotional bond, which shapes cultural and patriotic attitudes. All respondents also appreciated the recreational role of a trip and how it is an opportunity to improve health and fitness.

Therefore, a field trip should be a more frequently used form of early childhood education, both in the kindergarten and family. Teachers and parents should search for sources of inspiration and learning programs through tourism and local history exploration. Many of such initiatives can be found in literature and on websites. Among others, the project of cooperating networks between

\footnotetext{
16 S. Witek, Kindergarten field trips, CDN, Kalisz 1986, p. 4.
} 
The Small Kindergartens. ${ }^{17}$ The Small Tourist Kindergartens project aims to develop tourism in selected kindergartens, promote agritourism in the countryside and its surroundings as well as to engage preschool children and their families, along with the personnel of the institutions, in the development of the pro-family tourism offer of the town and the region of Lower Silesia. The Kindergarten No. $13^{18}$ in Elbląg is the only tourist kindergarten in Poland. The institution promotes tourism by integrating kindergarten community. The kindergarten organizes and participates in rallies, tourist and sport events together with parents and all employees of the nursery in cooperation with the PTTK Earth Elblag. Another initiative is the tourist program of the "Acacia Hill " public kindergarten in Lagiewniki. ${ }^{19}$ The basic idea of the program is to encourage children and their parents to spend free time actively, healthily and productively. Children's main task which engages all their attention is to explore the local and distant environment, its natural elements, traditions, cultural monuments, its history, the myths and legends as well as to win the "Seven-league boots" tourist badge.

These exemplary actions taken by the kindergarten can be a source of inspiration for other institutions in order to disseminate tourism in early childhood education, or at least to encourage more frequent trips, which according to H. Gutowska ${ }^{20}$ are like opening "a window on the world", they are a preparation for independent expeditions satisfying curiosity and an implementation of the activity connected with exploring local history.

\section{References}

Budniak A., Social-environmental education of preschool and primary school aged children, IMPULS, Kraków 2010.

Denek K., Trips in the modern school, ERUDITUS, Poznan 1997.

Dymara B., Michałowski S., Wollman-Mazurkiewicz L., A child in the natural world, IMPULS, Kraków 1998.

Gutowska H., Social and natural environment in I-III grades. The practicum handbook, WSiP, Warszawa 1989.

\footnotetext{
$17 \mathrm{https} / / /$ sites.google.com/site/maleprzedszkolaturystyczne.

18 http://www.info.elblag.pl/17,13492,Przedszkole-ktore-promuje-turystyke-i-zdrowie. html\#ixzz3440YqoRw.

19 http://www.przedszkole.lagiewniki.pl/program\%20turystyczny.htm.

${ }^{20}$ H. Gutowska, Social and natural environment in I-III grades. The practicum handbook, WSiP, Warszawa 1989, p. 173.
} 
Lewicki C., Factors determining the course, the quality and the effects of health education of 6-11 year old children in the family, WSP, Rzeszów 2001.

Łobożewicz T., Sightseeing and tourism at school, WSiP, Warszawa 1985.

Sawicki M., Environmental education in I-III year of primary school, Semper, Warszawa 1997.

Studzińska M., Pre-school children learn about nature, WSiP, Warsaw 1989.

Witek S., Kindergarten field trips, CDN, Kalisz 1986.

Wojciechowska K., Excursion as a basic form of tourism and sightseeing in the preschool aged child's education, Rozprawy Naukowe AWF we Wrocławiu No. 46, Wrocław.

\section{Websites}

https://sites.google.com/site/maleprzedszkolaturystyczne/http://www.info.elblag. pl/17,13492,Przedszkole-ktore-promuje-turystyke-i-zdrowie.html\#ixzz3440YqoRw http://www.przedszkole.lagiewniki.pl/program\%20turystyczny.htm

\section{PRZYGOTOWANIE DZIECKA W WIEKU PRZEDSZKOLNYM DO TURYSTYKI I KRAJOZNAWSTWA}

\section{Streszczenie}

W edukacji przedszkolnej procesowi przygotowania dziecka do przyszłej roli turysty przypisuje się duże znaczenie. To, w jaki sposób już w przedszkolu zostanie ukształtowana postawa wobec turystyki i krajoznawstwa, będzie decydować o intensywności i wartości ruchu turystycznego dorosłych pokoleń. Proces wyzwalania aktywności turystycznej i zainteresowania otaczającą rzeczywistością kulturową, przyrodniczą, społeczną odbywa się głównie przez udział dzieci w wycieczkach. W artykule przedstawiono rolę wycieczki w kształtowaniu postawy krajoznawczej oraz we wszechstronnym rozwoju dziecka. Dokonano też analizy wyników badania sondażowego nauczycieli i rodziców, którego celem było poznanie opinii respondentów na temat warunków organizowania i znaczenia wycieczki w rozwoju społecznych, poznawczych, emocjonalnych i zdrowotnych obszarów osobowości dziecka oraz jego zaangażowania i przygotowania do aktywności turystycznej.

Słowa kluczowe: turystyka w przedszkolu, wycieczka jako forma turystyki, dziecko w wieku przedszkolnym 